\title{
Erodibility status of soils under different land uses in Longleng district soils of Nagaland
}

\author{
Manoj Dutta*, Bongkam Phom and Sewak Ram \\ Department of Soil and Water Conservation, School of Agricultural Sciences and Rural Development, \\ Nagaland University, Medziphema Campus, Medziphema (Nagaland) India \\ (Email : manojdutta1997@yahoo.com)
}

\begin{abstract}
Land use effect on soil erodibility parameters were studied in four villages, viz., Tamlu village, Tamlu town, Kangching and Namsang in Longleng district, Nagaland, under four land uses, viz., Jhum, lowland rice, forest and orange in each village. The mean textural class of the soils were clay and clay loam. Dispersion ratio and erosion index were recorded to be usually higher than the threshold limits. Dispersion ratio of the soils ranged from 11.08 to 71.83 where as, erosion index varied between 17.94 and 78.02. A significant and negative correlation of clay with dispersion ratio and erosion index was observed. The highly significant and positive correlation between erosion index and dispersion ratio indicated the susceptibility of these soils to water erosion. Proper agronomic and mechanical soil and water conservation measures need to be adopted to protect the soils from further degradation
\end{abstract}

Key Words : Land uses, Dispersion ratio, Erosion index

View Point Article : Dutta, Manoj, Phom, Bongkam and Ram, Sewak (2018). Erodibility status of soils under different land uses in Longleng district soils of Nagaland. Internat. J. agric. Sci., 14 (2) : 407-412, DOI:10.15740/HAS/IJAS/14.2/407-412. Copyright@ 2018: Hind AgriHorticultural Society.

Article History : Received : 14.03.2018; Revised : 10.05.2018; Accepted : 24.05.2018

* Author for correspondence: 